\title{
David in Medieval Jewish Thought
}

\author{
Judah Halevi's Book of the Kuzari as a Reconciliation Project
}

\author{
Marzena Zawanowska
}

\section{Introduction}

King David is one of the most complex, rich, and ambivalent characters in the Hebrew Bible. ${ }^{1}$ He is described as a brave warrior and an efficient ruler, but also as a vassal of the Philistine king - a sort of a mercenary soldier - and a sinner, criticized in Scripture itself for his morally reprehensible dealings with Bathsheba. Notwithstanding this mixed legacy (or perhaps because of it), he became a central figure in all of the monotheistic traditions. Each of these traditions significantly reinterpreted him and his life story to the effect that, with time, he has become chiefly associated with the (albeit more imagined than real) idyllic past of the United Kingdom of Judah and Israel and with messianic hopes for ultimate redemption in the future. In addition, all these traditions rendered him the pious author of the entire book of Psalms, despite the fact that the Bible makes no such claim, and in fact overtly attributes some of the psalms to different authors. This last aspect of David's character was of particular importance for the medieval Jewish poets who lived in the Iberian Peninsula and wished to revive the Hebrew language and to imitate its beauty in their own poetical oeuvre. One of them, Shmuel ha-Nagid, went so far as to see a new incarnation of David in himself. ${ }^{2}$

1 The paper was prepared within the framework of the research project, "The Karaites and Karaism as Portrayed in Medieval Rabbanite Sources. A Comparative Study and Translation of Judah Halevi's Kuzari," sponsored by the National Science Centre (NCN; grant Opus 10) awarded to Dr. Marzena Zawanowska (2015/19/B/HS2/01284). I wish to express my gratitude to Ms. Tamar Cohen for her careful reading of this text and all the corrections and suggestions. Throughout the paper, I follow Barry S. Kogan's and Lawrence V. Berman's translation of The Book of the Kuzari with slight modifications and minor adjustments when necessary. I am very grateful to Prof. Kogan for having shared with me this translation prior to its publication. All the italicized phrases within the citations are in the original, while passages in bold as well as additions of Arabic words in brackets are my own.

2 See, in this volume, Gryczan, "David as Warrior, Leader, and Poet." 
In this paper, I would like to focus on the work of another of these poets, Judah Halevi, and examine the reception of the biblical David in his opus magnum Kitāb al-radd wa-'l-dalïlfíl-din al-dalïl (The Book of Refutation and Proof on Behalf of the Despised Religion). ${ }^{3}$ This treatise in comparative religion, written in Judeo-Arabic in twelfth-century Spain (ca. 1130-1140), better known under its shortened Hebrew title Sēper ha-Küzarì (The Book of the Kuzari), or simply Küzari (henceforth spelled Kuzari), is one of the most important and influential texts of medieval Jewish philosophy and beyond. ${ }^{4}$ It is written in the form of a dialogue and uses a pseudo-historical story of the Khazars' coversion to Judaism (a motif popular in contemporaneous literary texts and oral tradition) as the narrative framework for an extensive religious debate between the nameless Khazar king and four wise men: the philosopher, the Christian, the Muslim, and the Jew. After a short debate (Kuzari 1:1-9), the king manages to contravene the arguments of the philosopher, as well as the Christian and the Muslim sages (who both confirm the truth of the Hebrew Bible) and decides to convert to Judaism. The rest of the book (Kuzari 1:10-5:28) reports his discussion with the Jewish sage whose long statements are only sparcelly interrupted by the king's inquiries and comments. The aim of my analysis is to scrutinize Halevi's outlook on the intriguing and colorful biblical character of David as emerging from this discussion, exploring how and why - if at all - the author instrumentalized David, as well as how far he strayed from the scriptural depiction of the figure.

Yet, before attempting to answer these questions and delving more deeply into Halevi's portrayal of David in the Kuzari, a few words needs to be said about the treatise itself. In many respects, it is one of the most difficult and ambiguous texts written in the Middle Ages. Little wonder, therefore, that scholars offer divergent interpretations not only of the text itself but of the whole question of the purpose of its writing. ${ }^{5}$ The common denominator of the various approaches is that their authors try to find an ordering principle to help them understand the enigmatic composition by providing an

3 This title appears in Ms. Cambridge, T.-S. Arabic N.S. 308.86. An alternative title, Kitāb al-huğğa wa-'l-dalïl fì nașrat al-din al-dalïl (The Book of Sign and Proof of the Victory of [or "in Support of"] the Despised Religion), is attested to in Ms. Oxford, Bodleiana, Poc. 284. On both these Mss., see Yehudah Halevi, The Book of Refutation, '-ט. On the title, see ibidem, יאיביב.

4 For a seminal study of the reception of this text in Jewish tradition, see Shear, The Kuzari.

5 For an overview of different scholarly approaches to this text, see Berger, "Toward a New Understanding"; Zawanowska, "Introduction. Yehudah ha-Levi and His Book of the Kuzari." For a review of scholarship dealing with The Book of the Kuzari and main research trends, see (still valid) Lobel, Between Mysticism and Philosophy, 6-9; Shear, The Kuzari, 2-12. 
interpretative key to it. ${ }^{6}$ My paper represents another voice in this ongoing discussion. Accordingly, I will use the figure of David not only as an instructive, illuminating example of Halevi's engagement with biblical materials, but also as a tool to address the more general question of the purpose of writing of his treatise.

\section{$2 \quad$ Omissions: De-biblicization}

David is one of the most frequently mentioned biblical characters in The Book of the Kuzari - third after Moses and Abraham - while the book of Psalms, which Jewish tradition attributes to him, is referred to more often than any other biblical text with the exception of the Torah. This stands in contrast to other famous medieval philosophical texts, such as Sa'adya Gaon's (d. 942) Kitāb al-amānāt wa-'l-itiqādāt (The Book of Beliefs and Opinions), Bahya Ibn Paquda's (mid-11th c.) Darāib al-qulūb (Duties of the Hearts), or Moses Maimonides' (d. 1204) Dalälat al-hä'irin (The Guide of the Perplexed), where the figure of David is almost absent, even though their authors do frequently refer to the Psalms.

Against this backdrop, The Book of the Kuzari, with its seventeen mentions of David in different contexts, stands markedly out, although - as we will see Halevi's David preserves little if anything of the character's biblical prototype. The treatise does not present a single narrative or historical event related to this figure alluded to so (relatively) often by the author, nor are there any traces of his colorful adventures or of the historical context of his times as described in the Bible. As a result, David himself becomes flat and faded. In fact, he ceases to be a historical and/or literary character altogether, and thus, in a way, becomes a non-biblical figure. This first trend in Halevi's reception of the biblical David can thus be called "de-biblicization."

Here it may be instructive to observe that, according to Halevi, the biblical authors themselves were selective, not putting in writing all that they knew about David, or about other biblical characters, for that matter. The difference between those authors and the medieval thinker is that while the latter omits the more down-to-earth (factual and material) aspects of David's depiction, the former - at least in Halevi's view - were silent about his more spiritual (prophetic and intellectual) aspects. In Kuzari 3:63, we read:

6 See Berger, "Toward a New Understanding." 
[...] the biblical historian (or "chronicler"; Ar. mu'arrih) was not interested in things that are recondite, but in things that are well-known, things that are public. Accordingly, in connection with Joshua, he did not mention a thing about his knowledge, which was passed down [to him] from God, exalted be He, and also from Moses, peace be upon him. ${ }^{7}$ Rather, he mentioned only the day when the Jordan halted its flow, ${ }^{8}$ and the day when the sun stood still, ${ }^{9}$ and the day of the mass circumcision ${ }^{10}$ because of their notoriety among the multitude. The same is true of the stories (Ar. ahbār) of Samson, Deborah, Gideon, Samuel, David, and Solomon. He did not mention anything about their knowledge nor anything about the traditions they had with regard to the Law (Ar. al-atāar fi al-šaría); but he did mention some of the stories about Solomon, his great feasts, ${ }^{11}$ and his immense wealth. ${ }^{12}$ Again, he did not mention any of his rare feats of knowledge, except for [the story that begins], Later, two prostitutes came [to the king ...], ${ }^{13}$ since the affair came to its conclusion in the presence of the multitude. As for his wisdom ${ }^{14}$ in connection with the Queen of Sheba ${ }^{15}$ and others, he did not mention that either, since it was not the purpose of the author (Ar. al-mudawwin) to mention anything except what was well-known to the multitude, which the entire community has preserved.

Halevi conjures up a conception of the biblical author-redactor or compilereditor (Ar. mudawwin) - initially introduced by medieval Karaite exegetes - in support of the authenticity of oral tradition, which, in his view, existed already in biblical times. ${ }^{16}$ Thus, this assertion reflects his subversive use of a typically Karaite concept to polemicize against the Karaites' rejection of the Oral Torah. He claims that the author (or authors) of historical reports in the Bible (Ar. mu'arrih) was selective, putting into writing only those things that were

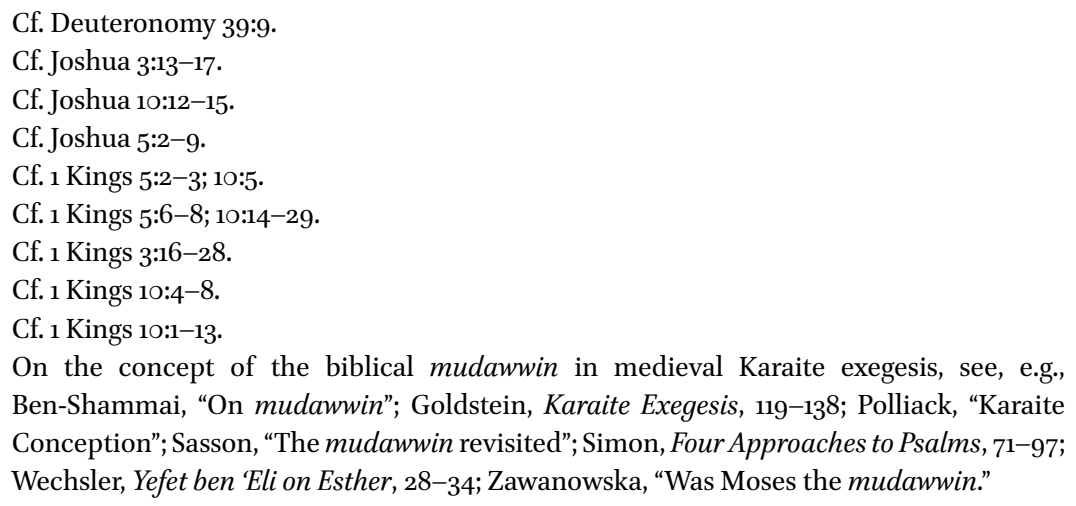
Ben-Shammai, "On mudawwin"; Goldstein, Karaite Exegesis, 119-138; Polliack, "Karaite Conception"; Sasson, "The mudawwin revisited"; Simon, Four Approaches to Psalms, 71-97; Wechsler, Yefet ben 'Eli on Esther, 28-34; Zawanowska, "Was Moses the mudawwin." 
"well-known to the multitude, which the entire community has preserved." Accordingly, he mentioned nothing about David's and other biblical characters' "knowledge nor anything about the traditions they had with regard to the Law (Ar. al-atāar fíal-šarîa a." In other words, Halevi was of the opinion that different biblical characters, including David, were transmitters of the Oral Torah, but this fact is not explicitly acknowledged in the Bible because they did not receive the knowledge of "traditions [...] with regard to the Law" publicly ("in the presence of the multitude"), and as a result "the multitude" was unaware of their possession of it.

Thus, the main target of Halevi's polemic here are the opponents of the Oral Torah, most notably, the Karaites, while his line of defense is that the knowledge of traditions has been a recondite possession of the privileged few. Interestingly, the concept that the knowledge of truth rests with and is transmitted by the elite of the few selected individuals - the chosen ones (Ar. safwa), who preserve it in secrecy (nota bene, well known from Shicite writings) - appears also, mutatis mutandis, in Karaite discourse. ${ }^{17}$ The difference between the Karaite conception of the righteous remnant (Heb. šěerït) and the idea of safwa is that the latter is an inherited, genetic quality which, according to Halevi, characterized all of Israel (Jacob’s offspring), while šěerìt is not biologically dependent. Rather, it refers to a small group or community within Israel (out of the entire nation) that remained loyal to the true Torah and occupied itself with its study and teaching. ${ }^{18}$ Another difference is that the Karaites argued that the true knowledge of which they claimed to be in secret possession is different from (or an alternative to) the Rabbanite tradition, which they considered "a commandment of men learned by rote" (Isaiah 29:13), while Halevi maintains that the Oral Torah constitutes this true knowledge transmitted secretly. Hence, this comment reveals how Halevi skillfully interplays ideas drawn from the different sources at his disposal - including Karaite ones - by subjecting them to subversive interpretations.

17 On the Shi ite concept of șafwa and its influence on Halevi, see Krinis, God's Chosen People; idem, The Legitimist Inheritance. On the more general Arabic background of Halevi's treatise, see idem, "The Arabic Background," and further bibliography there.

18 I am grateful to Prof. Daniel Lasker for bringing this issue to my attention. On the Karaites' self-perception as a community that was forced in the past to remain in hiding, see Yefet ben 'Eli's comment on Zechariah 5:9-11, where he declares: "The supporters of truth (Ar. ahl al-haqq) had been subdued and [made] invisible [presumably, by the majority who embraced the Oral Torah] until the time of the appearance of the little horn (Daniel 7:8 = Muhammad), who [...] enabled [selected] individuals from [the children of] Israel to disclose something of the truth in the kingdom of the little horn [= Muslim empire]." I am grateful to Kees de Vreugd for having permitted me to read his edition of Yefet's commentary on Zechariah prior to its publication. 
To generalize, we can say that Halevi exhibits interest in subjects that are ignored (or purposefully passed over) and underrepresented in Scripture, while he shows no concern for the dominant aspects in the biblical depiction of David, namely, things that were "well-known," and "public" such as his stormy life story, replete with military bravado and romantic exultation.

Having discussed what Halevi omits, now the question may rightly be asked: what did he decide to preserve? What remains of the intriguing biblical figure of David in The Book of the Kuzari? What aspects did the medieval author choose to highlight? Moreover, what did he add to David's representation, and why?

\section{3}

\section{Preservation: Idealization}

As might be expected, from among the numerous and variegated biblical reports on David, Halevi carefully chooses chiefly those aspects of his scriptural representation that bespeak of his spirituality. Not only does he preserve, but also emphasizes - or even over-emphasizes - them, thereby idealizing David's image. A good example of how Halevi plays with the biblical materials, placing into relief David's prophetic powers and downplaying other, more carnal, aspects of his biblical depiction, may be adduced from Kuzari 1:99, where we read:

[...] the shape of the Tabernacle in its entirety was shown to Moses on the mountain [...]. Similarly, the revered house that Solomon built was one of the things whose form was shown to David in a spiritual way. ${ }^{19}$

Referring to a passage from Chronicles (1 Chronicles 28:11-13), Halevi emphasizes that David, like Moses before him, was privy to prophetic visions. His received prophecy, moreover, related to the most central aspects of religious life of Israel - and a central theme of Halevi's [proto-] Zionist thought namely, the Temple. In this context, Halevi focuses on David's spirituality while omitting the fact that, just a few verses earlier, God says to David: "But God said unto me: Thou shalt not build a house for My name, because thou art a man of war, and hast shed blood" (v. 3) - a detail that signals David's entanglement in physical brutality and violence, and as such reflects badly on the biblical figure.

Yet, David's association with the Temple, in Halevi's view, goes well beyond his involvement in its building (in terms of planning its shape). Firstly, the

19 Cf. 1 Chronicles 28:11-21. 
author indicates that it was only in David's time that the exact site where the Temple was to stand was revealed (see Kuzari 2:14). Secondly, and most importantly, David is associated with introducing and establishing the rules of cultic ritual in the Temple. In Kuzari 3:39, Halevi asserts:

[...] At times, we do see something that was enacted after Moses, and it became a Law (Ar. šara), as for examples, when Solomon consecrated the center of the court and offered burnt offerings at a place other than the altar ${ }^{20}$ and held the feast ... [for] seven days and again seven days. ${ }^{21}$ There is also what David and Samuel put into proper hierarchical order with respect to the arrangement of the singers in the Temple, and it too became a Law that endured (Ar. šara ${ }^{c a n}$ mustamarran). ${ }^{22}$ Again there is what Solomon did in connection with the Tabernacle [...]; and there is also what Ezra wrote down for his community during the Second Temple period with respect to contributing one third of a shekel ${ }^{23}[\ldots]$.

According to this passage, David (together with his son, Solomon) is attributed with the establishment of the religious cult in the Temple with its specific rituals and musical arrangements. ${ }^{24}$ Thus, he is considered by Halevi not only as a recipient and transmitter of the Oral Law (see Kuzari 1:99 above), but also as a lawgiver himself, a prophet (comparable to Moses) through whom religious legislation was occasionally revealed. ${ }^{25}$ Incidentally, a similar idea is also

$20 \quad 1$ Kings 8:64.

211 Kings 8:65.

22 Cf. 1 Chronicles 9:22, 33; 2 Chronicles 5:12-13.

23 Nehemiah 10:32.

24 This comment is interesting as it suggests that the revelation of religious law (Ar. šara) did not end with Moses, but continued with later biblical prophets. In contrast with Karaism, the traditional Jewish outlook is that halakhah should be derived from the Pentateuch alone, and not from the entire Hebrew Bible, as it transpires from this passage, in which Halevi indicates that certain halakhic rulings were revealed also to prophets other than Moses, and were included in biblical books other than the Torah (and not merely passed through the oral tradition). Accordingly, this comment seems to reflect more a Karaite than a Rabbanite view of the Hebrew Bible as a text which in its entirety constitutes a legitimate source of religious legislation. It is not inconceivable that Halevi observed that the Rabbanite Jews in fact derived halakhah from the entire Hebrew Bible just like the Karaites did (e.g., selling on Shabbat is forbidden on the basis of Amos 8:5, while doing business in the sense of buying and selling, is only forbidden in Nehemiah 10:32; 13:15-22). The last example, of a contribution of only "one third of a shekel" recommended in Nehemiah 10:33, is most telling given that it may be understood as contradicting an explicit ruling included in the Pentateuch (see Exodus 30:11-16; 38:25-26), which imposes a contribution of "half a shekel." This apparent contradiction found various solutions] in 
expressed in Kuzari 3:41 (this time, however, with no mention of David), where the author expounds:

[...] Thus, the statement, You shall not add anything to what I command you or take anything away from it ${ }^{26}$ has come to mean: [You shall not add to or take away from] all that I have commended you through Moses and all that I have commanded you through a prophet from among your people, ${ }^{27}$ in keeping with the conditions that establish [fitness] for prophecy, ${ }^{28}$ or, all that the priests and the judges have agreed upon from the place which $\mathrm{YHVH}$ shall choose ${ }^{29}$ for they are indeed supported by the Divine Presence (Heb. Šekinā).

Here Halevi seems to equate Moses with other prophets, asserting that divine commandments were revealed also thorough these. In addition, he mentions the traditional authorities of the Oral Law (considered its earliest transmitters in the chain of tradition), namely, the priests and the judges, but, interestingly, their rulings are only binding, in his view, on the condition that they are declared in Palestine ("from the place which YHVH shall choose" [Deuteronomy 17:10]). Such a Palestinocentric statement seems to implicitly undermine the authority of later Jewish religious leaders active outside of Palestine, in the diaspora after the destruction of the Second Temple, like the sages of the Babylonian Talmud. To be sure, a similar notion was endorsed by the Karaites, who rejected the authority of the "shepherds of the exile." Although Halevi never says so explicitly, it seems that he is less enthusiastic about the Oral Torah produced outside of the Land of Israel than that which originated in Palestine. This is borne out by the fact that in his chain of tradition, he writes laudably as well as profusely and in detail about the sages of the Mishnah (Kuzari 3:64-67), while to the sages of the Talmud he devotes solely two sentences. In Kuzari 3:67, he declares:

As for the traditions of the Talmud and those who transmitted them, an account of them, their methods, their extraordinary aphorisms,

Jewish halakhic exegesis. Yet for our current discussion it is important to note that Halevi treats an enactment from the Book of Prophets as law (Ar. šara $\left.{ }^{\dagger}\right)$. On the debate over this subject during the second Temple period, as well as in the medieval Karaite and Rabbanite halakha, see Erder, Methods, 145-15o, 155-164; idem, "Half-Shekel Commandment."

26 Deuteronomy 4:2.

27 Deuteronomy 18:15.

28 Cf. Deuteronomy 18:21-22.

29 Cf. Deuteronomy 17:10. 
and their parables would take far too long to discuss. Even though they contain things that are not regarded as praiseworthy today (Ar. $l \bar{a}$ yustahsanu al-yawm), in those times they were useful and were regarded as praiseworthy.

Thus, in the first sentence, he dismisses the Talmud with a hardly convincing excuse that it "would take far too long to discuss" it. Furthermore, the second sentence seems to suggest that the wisdom included in the Talmud is not universal and eternal, but rather dependent on a specific time and place, which would not be the case had Halevi believed it was of a revealed nature. This not particularly flattering description of the Talmud (an exilic product, at least in terms of its more acclaimed Babylonian version, and written in Aramaic) stands in blatant contrast with Halevi's highly appreciative depiction of the Mishnah (edited in the Land of Israel and written in Hebrew), which is, in his view, of inimitable beauty and perfection of style, and therefore, he concludes, "human beings simply fall short of composing anything like it, unless it is with Divine Assistance" (Kuzari $3: 67){ }^{30}$ Thus it seems that, as opposed to his view of the Mishnah, Halevi might not have considered the Talmud to be a revealed or divinely inspired text, an inherent part of the Oral Torah given to Moses at Mount Sinai together with the Written one. This supposition seems to be further corroborated by a statement in Kuzari 3:73, where he describes it as a human compilation of the sayings of sages, prepared by their eager pupils who made diligent efforts (Ar. iğtihād) to faithfully transmit the teachings of their

30 The passage on the Mishnah reads: "[...] They [= the sages] show the same concern for the Mishnah that they showed for the Torah with respect to organizing it, arranging it, numbering the orders, chapters, and halakhic rules, as well as preserving the reports transmitted, all of which makes it improbable to believe that it is only something conventionally agreed upon. Moreover, in terms of good classical Hebrew, it includes much that is not derived from the language of Scripture. As for the conciseness of its speech, the beauty of its structure, and the excellence of its composition (Ar. ìgāz kalämihā wa-husn nizāamihā wa-ğawda tașnīfihā), encompassing aspects of the meanings [they discussed] authoritatively and decisively, without doubt and conjecture, it is at the cutting edge. He who considers it with an eye for the truth will see that human beings simply fall short of composing anything like it, unless it is with Divine Assistance. No one will register opposition to it except those who are ignorant of it and have not been engaged in reading and studying it." It seems reasonable to assume that Halevi's laudatory description of the Mishnah constitutes an apologetic response to the objections raised against it by the Karaites. See, e.g., the second and third chapters Salmon ben Yerūhīm's polemical treatise Sēper milhāmōt Adonai (Book of the Wars of the Lord), where he criticizes the Mishnah's content (i.e., the fact that it cites opposing views and includes internal contradictions), as well as its language and style, all of which prove, in the author's view, that it is a human composition. See Davidson (ed.), Book of the Wars of the Lord. 
masters. ${ }^{31}$ We can fathom the seriousness of this allegation only if we bear in mind that relying on individual intellectual effort (Ar. iğtihād), instead of following tradition, was one of the major allegations advanced by the Rabbanites against the Karaites. Hence, Halevi is presumably making subversive use of a concept conventionally employed to denigrate the Karaites, to implicitly criticize the Rabbanite tradition that originated outside of the Land of Israel. ${ }^{32}$

Parenthetically, it is a matter of conjecture, but it seems to me not unlikely that rightly because of such statements, Abraham Ibn Da'ud chose to respond

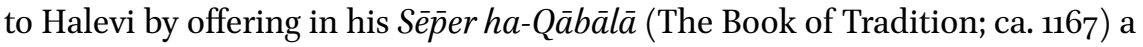
historical reconstruction of an unbroken chain of oral tradition from Moses up to community leaders in twelfth-century Spain, including its reliable transmitters active in the exile. ${ }^{33}$ By doing so, he arguably intended to prove - against Halevi's claim - that the leaders of the diaspora were as much legitimate religious authorities as the tannaitic sages in Palestine.

Returning to our subject, however, we may say that, arguably, one of the most important aspects of the representation of David emphasized (or over-emphasized) by Halevi is his affiliation with the Temple and its cult, as well as his prophetic powers, which made him partake in divine revelation.

31 We read there: "Now I do not deny, O king of the Khazars, that there are things in the Talmud about which I cannot convince you, nor can I even prove that they belong to a [single] domain. They are the things which the Talmud simply brought together because of the diligent effort (Ar. iğtihād) of the disciples [of the Sages], since they held to the view that even the ordinary conversation of the Sages requires study (b. Abodah Zarah 19b; b. Sukkah 21b). Their sole intent was to state only what they had heard from their masters, while at the same time making a diligent effort (Ar. iğtihād) to pass on everything that they had heard from their masters. In that regard they were also intent on [reporting] their exact words. Now sometimes they did \{not\} understand what they meant, and so they said, 'Thus we were told, and [thus] we have heard'. But sometimes, the master had certain aims with regard to that subject, which were concealed from his students. And so the matter [in question] reached us, and we attached no importance to it because we did not know his aim. However, all of this pertains to what is neither permitted nor forbidden. Therefore, [practically speaking,] we need not be concerned with it. Nor will it harm the work [if we adopt this stance], notwithstanding the different viewpoints that we have mentioned."

32 It might be that at the time (at least in al-Andalus) the Talmud did not enjoy as prominent a position as it is usually assumed. Tellingly, Maimonides does not mention the Oral Torah in his principles of Jewish faith, presumably intending to have the Talmud replaced with his own work, the Mishneh Torah, which would not be the case had he believed it was of a revealed nature. For more on the status of the Talmud in al-Andalus, see Fishman, Becoming the People of the Talmud, 65-120.

33 See Cohen, Sefer ha-Qabbalah. For an argument that Halevi's Kuzari was polemicizing against the Andalusian Jewish bourgeois society, see ibidem, L; Lasker, Judah Halevi and Karaism; idem, From Judah Hadassi. 
Yet, there are also other personal features of the biblical character that Halevi chooses to highlight, such as his being a wise philosopher and/or theologian (Kuzari 3:11), a sage (Kuzari 5:20), a righteous, pious believer who knows how to praise God and His Torah in an exemplary fashion (Kuzari 2:56), a gifted poet enjoying ultimate command of the Hebrew language (Kuzari 2:68), and a brilliant musician (Kuzari $2: 64) \cdot{ }^{34}$

Thus, at first sight, Halevi's reception of David seems to reflect a conventional, idealized representation of the biblical figure. Nonetheless, for our current discussion it is important to note that the thinker's portrayal of David is connected with key ideas in his thought, and, at the same time, the main foci of his reflection in The Book of the Kuzari, namely: (1) the Land of Israel, ${ }^{35}$ with Jerusalem and the Temple; (2) the Chosen People, with their unique gift of prophecy; and (3) the Bible and the Hebrew language in which it was written. Hence, from this perspective it appears that David plays a pivotal role in Halevi's treatise, constituting an axis of his discussion of the paramount issues treated in the text.

In addition, some scholars maintain that The Book of the Kuzari is a messianic or eschatological text. ${ }^{36}$ Even if we do not accept this claim, it is worth noting that, David is also mentioned in connection with the Messiah who will come from David's House (see Kuzari 3:19, 3:65, 3:73). In Kuzari 3:73, Halevi expounds:

[...] Still, some of them are obviously impossible, but their aim becomes clear with the slightest reflection. An example would be their statement: Seven things were created before the world: The Garden of Eden, the Torah, the righteous, Israel, the Throne of Glory, Jerusalem, and the Messiah, son of David, ${ }^{37}$ which corresponds to the saying of the learned, "What is first in terms of thought is the last in terms of action." ${ }^{38}$ Now, since the intention of $\{$ wisdom in the creation of this world was the Torah, which is the very embodiment\} of wisdom, while those who carry it are righteous, and the

34 For Halevi's lengthy discussion of Psalm 104 and his view that it recapitulates the description of creation in Genesis 1-2, see Halevi, Kuzari 5:10.

35 Halevi calls the Land of Israel "the gates of Heaven," and generally uses the Arabic term al-Šām to denote it.

36 See Dinburg (Dinur), "The Immigration of Rabbi Judah Ha-Levi"; Schwartz, "The Messianic Idea." For an argument that it is a mystical treatise, see Wolfson, "Merkavah Traditions." Cf. also Lobel, Between Mysticism and Philosophy.

37 See b. Pesahim 54a; b. Nedarim 39b; Genesis Rabbah 1:4. Cf. Albeck and Theodor (eds.), Midrash Bereschit Rabba 6.

38 Cf. Aristotle, On the Soul, III:10, 433a, 16-17. 
Throne of Glory dwells among them, and [since,] in reality, the righteous belong only to the choicest [offspring of Adam] (Ar. șafwa), ${ }^{39}$ namely, Israel, and only the most distinguished locale is appropriate for them, namely Jerusalem, and [since] only the noblest of human beings may arrange them in the proper order, namely the Messiah, son of David, and [since] their natural propensity as well as their life's journey are directed towards the Garden of Eden, it was necessary to assume that these things were already created in potentiality, before the world itself was actually created.

Citing an old rabbinic midrash, Halevi discusses what he considers to be the most important (interrelated) ideas of Judaism: namely the three physical or material concepts of the Torah, the people of Israel, and the holy land - with Jerusalem and the Temple as its epicenter, or the geographic holy of holies; as well as the three more spiritual or temporal notions of creation, revelation, and redemption, the last of which relates back to the lost Garden of Eden and is epitomized in the figure of the Messiah, son of David. As a result, David once again appears at the center of an important ideological discussion, related to the key notions and fundamental subjects of the entire treatise.

Now, it is important to note that all the above-mentioned ideas were negotiated throughout the Middle Ages. Jewish exegetes, thinkers, and sages of different denominations pondered the following questions: What does divine revelation include, in other words, what is the Torah - solely the Written or also the Oral Law? What should be the basis of religious legislation (Heb. hălākna $\bar{a}$ the Pentateuch alone, or perhaps the entire Hebrew Bible? Who is allowed to interpret Scripture and what is its legitimate, binding interpretation? Who are to be counted as the people of Israel - only the Rabbanites or also the Karaites? How about the converts - are they to be considered part of the people of Israel? And if so, should they be treated in every respect on equal terms with the native-born Jews? Is it necessary to live in the holy land or perhaps is it equally possible to lead a truly Jewish life in the diaspora? ${ }^{40}$ Is the Temple desirable, necessary even, for the proper fulfilment of divine commandments and leading an exemplary religious life, or did the liturgical cult and individual prayers replace it? Also, how should we understand creation - was it really $e x$ nihilo, or perhaps more in line with the neo-platonic concepts of emanation?

39 On the Shicite concept of șafwa, see above, n. 17.

40 On the Rabbanite sages' opposition to emigration to Palestine, discussed in the context of Karaite call for the return to the Land of Israel, see, e.g., Erder, The Karaite Mourners of Zion, 416, and further bibliography there. 
How to defend the notion of divine creation in face of the Aristotelian idea of the eternity of the world? And finally, should we patiently wait for the ultimate redemption or rather actively engage in ushering it in?

In The Book of the Kuzari, Halevi takes a stand - to be sure, not always in agreement with the mainstream Rabbanite position - in this important ideological debate, not infrequently invoking the character of David when addressing these paramount issues as an instrument for conveying his own ideas.

\section{Additions: Instrumentalization}

So far we have seen what Halevi omitted and what he preserved and emphasized (or over-emphasized) from the biblical character of David. Nevertheless, for our current discussion it is even more interesting to explore what he added to the biblical depiction of David. Already the title of the work - Kitāb al-raddsuggests that it is a polemical treatise. The question is, however, against whom does it polemicize? ${ }^{41}$

\subsection{Anti-philosophical Polemics}

Some scholars have considered The Book of the Kuzari as an essentially antiphilosophical treatise. ${ }^{42}$ Even if such an interpretation may appear too farfetched, it certainly includes polemical pronouncements directed against specific philosophical currents or schools and trends, as well as selected individual philosophers. In one such pronouncement David is mentioned. In Kuzari 5:8 we read:

[...] That's the argument [with which we could refute the proponents of chance]! And [it would be] all the more [successful, if it were combined] with our apprehending some of the wisdom inherent in many of those things and [understanding] why they are needed, as has been explained in Aristotle's book, On the Utility of the Various Kinds of Animals, and Galen's book, On the Utility of the Limbs, and in other works besides those which are concerned with the wonders of [divine] wisdom. In the same way, it becomes clear that domestic animals like sheep, cattle, horses, and asses exist on account of man's need for them because they are not suited

41 For an argument that the main purpose of the treatise was an apologetic defense of Judaism, see, e.g., Levinger, "The Kuzari”; Schweid, Reason and Analogy.

42 See Husik, A History; Strauss, "The Law of Reason." For an argument that Halevi's Kuzari is essentially a philosophical treatise (devoted to divine attributes), see Neumark, Essays. 
to be wild, but rather to dwell in a settled place for the benefit of human beings. In addition, everything that David, peace be upon him, alluded to, when he said, How great are your works, $O Y_{H V H} !^{43}$ is [alluded to] for the purpose of refuting the argument of Epicurus the Greek, who used to think that the world came into being by chance.

In this passage, Halevi invokes David to serve his own (anti-philosophical) purposes, by depicting this biblical character as an anti-Epicurus polemicist, despite the fact that, chronologically speaking, the Greek philosopher lived many centuries after the biblical king (fourth-third C. BCE; 34O-27О BCE).

\subsection{Anti-Karaite Polemics}

A more common (and dominant) conviction, however, is that The Book of the Kuzari was chiefly written as an anti-Karaite polemic. ${ }^{44}$ It seems to be confirmed by a letter found in the Cairo Genizah, where Halevi admits to having written it "in response to the request (or 'demand') of one of those who embraced heresy (Heb. minūt)."45

In a nutshell, the most conspicuous allegations against the Karaites and at the same time the main bone of contention between them and the Rabbanites - concern two interrelated subjects: Scripture (and its interpretation), and calendar. Now, if we check The Book of the Kuzari with reference to these two much disputed issues, we shall see that David appears in crucial moments of Halevi's discussion of the subjects.

\subsection{The Torah}

As to the first allegation, the Karaites did not recognize the binding nature of the Rabbinic tradition, replacing it - at least at the formative stage of the

43 Psalms 104:24.

44 See, e.g., Baneth, "Some Remarks"; Friedman, "Judah Ha-Levi"; Goitein, "The Biography." For an argument that at least the entire third chapter of the treaties may be considered an anti-Karaite polemic, see Astren, Karaite Judaism, 198, n. 51 ("[...] all of part 3 can be read as an anti-Karaite argument"). Cf. Schweid, Reason and Analogy.

וכאן סבבה טלבה אחד מנתחלי אלמנות בבלאד אלרום סאלני פי אגראץ' פארסלתה

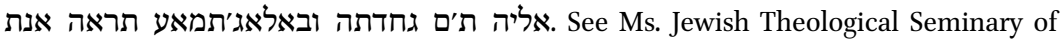
America, ENA NS 1, fol. 5 (L no. 41, "list 4"), plate 7. For its edition and Hebrew translation, see Goitein, "Autographs," 409 (Ar. and Heb.). English translation after Friedman, "Judah Ha-Levi," 161. See also Fleischer and Gil, Yehuda Halevy, 324-326 (Heb. and Ar.). Cf. Baneth, "Some Remarks," 297ff (Ar.), 302ff (Heb.); Friedman, “Judah Ha-Levi," 158. Goitein, "The Biography," 46-48; Goitein, Friedman, India Traders, par. 204. Cf. Goitein, A Mediterranean Society, vol. 5, 464-465; idem, Letters, s. 337; Schirmann, A History of Hebrew Poetry and Drama, vol. 1, 321 (Heb.). 
movement's development (in the ninth through the eleventh centuries) - with reason as the chief means for acquiring the proper understanding of Scripture. Accordingly, until the eleventh century, when the Karaites eventually established their own alternative tradition (Heb. ha'ataqā, sevel ha-yěrūshā), they promoted individual rational inquiry into the Law, offering alternative exegetical solutions and halakhic rulings, instead of relying on authoritative interpretations of the Sages. ${ }^{46}$

Halevi discusses the Karaites' rejection of the Oral Torah, arguing that Karaism emerged as a result of misinterpretation or misunderstanding of David's instruction given to his son, Solomon, when he said "know the God of your father and serve Him" (1 Chronicles 28:9). In Kuzari 5:21, he asserts:

[...] So, too, [you should] put aside what the Karaites cite as proof [for their misleading claims] in David's charge, peace be upon him, to his son, And now, my son, Solomon, know the God of your father and serve Him, ${ }^{47}$ as well as the inference they draw from it that one needs true knowledge of God [first], and [only] then does worshipping Him become obligatory. On the contrary, he urged only that [Solomon] faithfully follow the tradition (Ar. taqlid) of his father and his ancestors with regard to belief in the God of Abraham, the God of Isaac, and the God of Jacob ${ }^{48}$ whose providence had accompanied them and who fulfilled His promises to them regarding the great multitude of their descendants, the inheritance of Syro-Palestine (Ar. al-Šām), the indwelling of the Divine Presence (Ar. Sakina) [among them], and other things besides these.

According to this passage, the Karaites' "sin," and the reason for the split between them and the Rabbanites, comes down to an intellectual mistake in Bible interpretation; they simply failed to properly understand the prophet's words. While David had the tradition of the ancestors (Ar. taqlid) in mind, the Karaites wrongly took it to mean individual rational inquiries aimed at acquiring the knowledge of God (Ar. ma'rifat Alläh) as a prerequisite of religious practice (Ar. $i b \bar{a} d a) .{ }^{49}$ Thus, Karaism is construed as a consequence of

46 The difference between the Karaite and the Rabbanite conceptions of tradition is that, in contrast to the latter, the former is not considered to have been revealed by God, representing a consensus of Karaite sages (Ar. iğmā'; Heb. 'édā, qibūss). See Zawanowska, "Hacataqa."

$47 \quad 1$ Chronicles 28:9.

48 Cf. Exodus $3: 6,15 ; 4: 5$.

49 For an argument that this biblical verse, together with Deuteronomy 4:39 ("Know therefore this day and keep in mind that the Lord alone is God") "served the Karaites as slogans 
an exegetical mistake stemming from a misunderstanding of the intended meaning of Scripture, and resulting in a rebellious rejection of the teaching of the sages, as well as individualistic over-intellectualism. ${ }^{50}$ Halevi manages here to kill two birds with one stone by addressing at once the issue of the Karaites' rejection of the Oral Torah and their anarchistic individualism in Bible interpretation, which the author both deplored and opposed as inevitably leading to heresy (Heb. minūt) in the literal (etymological) sense of this word, that is disintegration of the Jewish community. ${ }^{51}$

In any event, this passage encapsulates the essence of the split between Rabbanites and Karaites, revolving around the polarizing categories of tradition and reason, and which, as I have argued elsewhere, is analogous to the Muslim division into ahl al-hadit tend ahl al-ra'y. ${ }^{52}$ The Karaites are construed as intellectual individualists and anarchists, while the lack of obedience to religious authorities is understood as their main fault. In a different place, in Kuzari 3:39, Halevi admonishes:

[...] We are ordered to obey the authorized judge in every generation, just as it says, $[\ldots$ and appear $]$ before the $[. .$.$] judge in charge at that time, and$ present your problem. When they have announced to you the verdict in the case, you shall carry out the verdict that is announced to you from the place that YHVH chose, observing scrupulously all their instructions to you. ${ }^{53}$ Then it adds, Should a man act presumptuously and disregard the priest, etc., [...] That man shall die. Thus you will sweep out evil from your midst. ${ }^{54}$

to express the doctrine that knowledge of the articles of faith must precede performance of the commandments, cognition comes before practice," see Ben-Shammai, "Major Trends," 346.

For an argument that, "according to Halevi, the fact that Karaites try harder [i.e., they use iğtihād] is a sign of their ultimate weakness," see Lasker, Judah Halevi and Karaism, 118-119; idem, From Judah Hadassi, 148. For Halevi explicitly admitting elsewhere that the Rabbanites also practice iğtihād, see above, a passage from Kuzari 3:47 cited in n. 1225 .

$5^{1} \quad$ In Kuzari 3:49 we read: "[...] they [= the Karaites] have ended up exercising arbitrary judgement out of their ignorance of those things changing the revealed Law (Ar. mugayyarīn fì al-šar'a), and bringing about heresy (Ar. musabbabin li-'l-minüt). By this I mean the proliferation of religious creeds (Ar. mada āhib), which is the root cause of the religious community's corruption (Ar. așl fisad al-milla) and its departure from the principle of one Torah and one law (Numbers 15:16). [...] It goes so far that in a house of ten people, there will be ten religious creeds!" Cf. Zawanowska, "The Art of Ambiguity."

$5^{2}$ See Zawanowska, "Reconstructing the Past."

53 Deuteronomy 17:9-10.

54 Deuteronomy 17:12. 
Scripture associated disobeying the priest and the judge with the very greatest crimes, when it says, Thusyou will sweep out evil from yourmidst. ${ }^{55}$

At face value, according to Halevi, obedience to traditional religious authorities, that is the sages, is required under penalty of the most severe punishments. And yet, his statement appears to be a double-edged sword, for it appears that the religious authorities to whom one should submit are only those who announce their verdicts "from the place that YHVH chose", that is those who are active in Palestine. Nonetheless, if it were so, it would again testify to Halevi's Palestinocentrism as well as his ingeniously subversive use of biblical verses wherein an apparent critique of the Karaites in fact undermines the validity of the Rabbanites' claim for religious authority.

\subsection{The Calendar}

As to the second allegation, another major point of disagreement and divergence between the Rabbanites and Karaites in the Middle Ages was the calendar. ${ }^{56}$ It is difficult to overestimate its role in the life of any religious community, as it serves to define the rhythms of its liturgy and worship, while different calculations may lead to most serious consequences, such as festivals being celebrated at different times. It is, therefore, no wonder, that since antiquity not only has the calendar been at the heart of many fervent religious debates, but not infrequently it has also caused rifts and divisions, bringing about the emergence of new sects or movements.

While Rabbanite Jews used a pre-calculated calendar based on astronomical computations and settled schemes, the Karaites did not accept this fixed calendar and proposed an alternative, lunar one, based on the direct observation of nature (the stage in the ripening of barley grain, called $a \underline{b} \underline{i b}$ ) and celestial bodies (especially the sightings of the new moon, called mōla $d$ ). Given the importance of the calendar itself and the role it played in religious debates, both sides had to somehow justify their respective decisions to rely on their chosen method.

The Karaites claimed their reliance on the text of Scripture in this respect. The Rabbanites, however, could not do so. In consequence, many different theories arose in the Rabbanite milieu with regard to the calendar's origin. Sa'adya Gaon (d. 942) went as far as to claim that it was revealed already to Moses (!) at Mount Sinai, as part of the Oral Law. ${ }^{57}$ However, at least since the thirteenth

\footnotetext{
55 Deuteronomy 17:7.

$5^{6}$ On the history of the Jewish calendar, see the seminal work by Stern, Calendar and Community.

57 See Seewald, Kitāb al-radd. Cf. Poznański, The Anti-Karaite Writings, 270-271.
} 
century, a more commonly accepted view (first formulated by Rav Hayye Gaon in the early eleventh century), held that it was introduced by Hillel b. Judah, a fourth-century rabbi who was considered to be of Davidic lineage. ${ }^{58}$

The idea of connecting the calendar with the House of David is endorsed also by Halevi, who nonetheless introduces a significant innovation to the discussion of the origins of the Jewish calendar, proposing a completely new, as-yet unknown, suggestion with regard to its dating. ${ }^{59}$ In Kuzari 2:64, Halevi expounds:

[...] With regard to knowledge of the spheres and their revolution, what became the science of intercalation is only one of its results. Moreover, the greatness of the basic principle of intercalation is known, ${ }^{60}$ and so is all that became firmly established because of it for this people, which is weak in terms of matter, but strong in terms of form. And how could this not be so, when it is not even noticed among the peoples because of its paltry size, despicable condition and dispersion? Yet the remnants of the divine Law organized them in such a way that by means of it they came to be as one. One of the most extraordinary of these remnants is the intercalation procedure, employed in accordance with the roots that have been passed down from the House of David concerning the lunar cycle, which has not proved to be faulty for twelve hundred years, while the observations of the Greek astronomers and others besides them have proved to be faulty and have also requires correction and supplementation after only a hundred years. This procedure remained sound because of its association with prophecy. ${ }^{61}$ If a distortion of even a minute had been associated with the original calculation, it would surely have become a scandal today because of the discrepancy that would have existed between the mathematical calculation of the new moon (Heb. mōläd) and the sighting of the new moon. Similarly, there is no doubt that they had scientific knowledge of the solar cycle as well as other cycles pertaining to the stars.

$5^{8}$ See Stern, Calendar and Community, 2001, 175-179. We read there "The theory that became dominant in the 13 th century (but was first voiced by Hayye Gaon; early eleventh century) was an attribution of the calendar to a Hillel b. Judah in 358/9 CE. This Hillel is identified in later sources as a patriarch of the House of Hillel the elder, who is given Davidic lineage in the Talmud." I am grateful to Prof. Stern for consulting on this passage with me.

59 In a private communication, Prof. Sacha Stern admitted that there were "countless medieval theories about who instituted the rabbinic calendar." And yet, surprisingly enough, in his detailed overview of different theories there is none resembling the one proposed by Halevi. See Stern, Calendar and Community, $175^{-179}$.

6o Cf. t. Sanhedrin 2; b. Roš Haššanah 19b-2ob; b. Sanhedrin 6b-13b.

61 Cf. Exodus 12:2. 
Thus, according to Halevi, the fixed calendar dates "twelve hundred years." The key question, however, is how to count this "twelve hundred years": from the author's (Halevi's) own time (eleventh-twelfth century), or from that of the Khazar king who is believed to have converted to Judaism (eighth-ninth century).

If counted from Halevi's own times, the fixed calendar would have been introduced, in the author's view, in the first century BCE or CE. Thus, it would give us approximately the time of Hillel the Elder (11O BCE-1O CE), associated with Davidic lineage already in the Talmud. ${ }^{63}$ If it were so, the emergence of Karaism and the appearance of the fixed calendar would concur in time.

Yet, it seems more plausible to me to assume that Halevi was not anachronistic, and that the "twelve hundred years" should be counted back from the time of the Khazar king in the treatise. In this case, the pre-calculated calendar appeared, in the author's view, as early as in the fourth-third century BCE, at the time when, according to Halevi, revelation had not yet ceased. ${ }^{64}$ I am inclined toward the second view. It significantly strengthens the position of the Rabbanite calendar by implicitly suggesting that it was of divine origin, being revealed through the prophets. To prove that the calendar was not invented but revealed, Halevi needed to date it to the times when prophecy was still with the children of Israel. Hence, it would be a polemical statement, formulated in disagreement with what was to become the dominant Rabbanite view.

Halevi's narrative is original when compared with (numerous) other existing theories in that it dates the calendar to much earlier times than the most commonly accepted views by about eight centuries (in fact, only Sacadya proposed an earlier dating). In addition, while Halevi dates the origins of Karaism

62 Another time, when Halevi mentions David (or more precisely the latter's House, bett David) in connection with the calendar is Kuzari 4:29, he again emphasizes that the knowledge of the calendar "has not turned out to be faulty up to this very moment."

63 Cf. $b$. Roš Haššanah 25a; $b$. Berakot 1oa; $b$. Baba Meșia 59b; $b$. Sanhedrin 89a. This view is attested to in Arabic sources. In his Calendar and Community, Stern expounds: "AlBiruni $(c .1000 \mathrm{CE})$ writes that some Rabbanites date the institution of the fixed calendar to approximately 200 years after Alexander the Great; whereas according to other Rabbanites, it was instituted after the destruction of the Second Temple by one Eliezer b. Paruah. This name is unknown in rabbinic literature, but there are some grounds for accepting it as a genuine Rabbanite tradition. Indeed, the name b. Paruah is found in 1 Kings 4:17 as Solomon's governor נציב of the region of Issachar; the tribe of Issachar is associated, in rabbinic literature, with calendar reckoning, and the term נציב, according to the Babylonian Talmud (b. Sanhedrin 12a), was used by the calendrical court as a code word for 'month'. In a rabbinic context, therefore, the name b. Paruah has clear calendrical connotations." Parenthetically, in The Book of the Kuzari, Halevi avers that Hillel the Elder was "of the Davidic seed." See Halevi, Kuzari 3:65.

64 According to Halevi, the prophecy ended in the year 312 BCE. See Halevi, Kuzari 3:67. 
to the first century вСЕ (the time of the conflict between the Hasmonean ruler and the Sadducees on the one hand, and the Pharisees on the other), he generally admits that the origins of heresy and divisions or schisms in Israel date to earlier times - the crucial period in Israel's history when prophecy ended. Thus, the emergence of the pre-calculated calendar would concur in time with the most important moments in the nation's life when it still resided in Palestine, and it is mentioned by Halevi in connection to the House of David. Parenthetically, this could be construed as bearing further testimony to the fact that the author was suspicious with regard to the oral traditions that originated outside of the Land of Israel, after the end of prophecy.

\subsection{Anti-Rabbanite Polemics}

Although Halevi seems critical of some of the Karaites' views and ideas, as we have seen, the Karaites are by no means the only target of his polemics, nor are they too harshly criticized by him. With respect to some matters, he even seems to take a pro-Karaite position, and as if this were not enough, he occasionally gives voice to anti-Rabbanite opinions as well. We have seen it in the case of his Palestinocentric views, which implicitly undermined the authority of the Rabbanite religious leadership remaining in the diaspora. Another apt example of Halevi's critique of the Rabbanite Jews in this respect may be adduced from Kuzari 2:22, where he declares:

[...] There is also their [= the sages'] saying that a person should always live in the Land of Israel, even in a city that is predominantly gentile; and he should not live outside of the Land, even in a city that is predominantly Jewish, because whoever lives in the Land of Israel is like someone who has a God, while whoever lives outside of the Land is like someone who has no God. It says the same thing in the words of David, "For they have driven me out today so that I cannot share in YHVH's possession, saying 'Go worship other gods."65 This means that everyone who lives outside the Land [of Israel] is like someone who practices idolatry. ${ }^{66}$

In this passage, Halevi cites classical Jewish sources in which David's words feature as a proof-text in support of the idea that living outside of the Land of Israel is tantamount to idolatry. Thus, the author once again offers a subversive reading of a rabbinic text, which he employs to undermine (or even reject altogether) the legitimacy of the Rabbanite way of life in the diaspora and to

65 See b. Ketubbot 11ob. Cf. 1 Samuel 26:19; b. Sanhedrin 41a.

66 See t. Abodah Zarah 5; b. Ketubbot nob. 
call for the return to Palestine. By doing so, he - inadvertedly or avertedly promotes Karaite ideas, by combatting those of the Rabbanites with their own weapon, a citation taken from the corpus of texts considered sacred in Rabbanite Judaism (i.e., the Oral Torah).

In contrast to Bible exegetes, medieval Jewish philosophers were generally not much interested in biblical literary narratives and historical reports. Little wonder, therefore, that the character of King David was not very popular in their writings, and if he was referred to, it was usually done in a conventional fashion. Accordingly, and notwithstanding a relatively frequent evocation of his name in The Book of the Kuzari, David's literary and historical dimension is absent in Halevi's treaties. I called this first major trend de-biblicization.

Only certain aspects of this biblical character's depiction remain and are emphasized or even over-emphasized, namely, those aspects that: (1) contribute to creating his positive image; and (2) accord with the key themes of the treatise, underscoring or illustrating the author's main points. As a result, not only does the portrayal of David become idealized, preserving little if anything in common with its biblical prototype (he is made into a perfectly wise sage, a model of religious piety and righteousness, as well as a brilliant poet and musician), but also it is instrumentalized, serving as a means of conveying Halevi's own ideas, including his polemical forays directed against philosophers, Karaites, and Rabbanites. To this end, the author exhibits no qualms about expanding the biblical representation of David and enriching it with new elements, implicitly suggesting that this expansion reflects actual truths about this figure that were deliberately passed over in silence by Scripture. Interestingly, to prove his claim, he enlists a Karaite concept of the biblical mudawwin, as a person responsible for the omission of information irrelevant and unknown to the masses.

Accordingly, the second major trend in Halevi's approach to David can be called instrumentalization, inasmuch as the biblical figure conveniently serves the author of The Book of the Kuzari as an instrument to underline what the latter considered to be the chief values and most important legacy of Judaism, namely: the Hebrew Bible (David as one of its authors); the Hebrew language (David as the author of the Psalms); the Chosen People with their unique gift of Prophecy (David as prophet); the Land of Israel with the Temple in Jerusalem as its "holy of holies" (David as responsible not only for providing the plans of the Temple, but also for establishing the cultic ritual in it). In addition, the 
figure of David is used for polemical purposes - as a vehicle for transmitting Halevi's constructive critique of contemporary Jewish society as a whole. His claim that the Law should be declared from Palestine may serve as an example here.

In the light of the above, I cannot agree with Leo Strauss who claimed that the "book is devoted to the defense of the Jewish religion against its most important adversaries in general, and the philosophers in particular." ${ }^{27}$ Nor is it, in my view, a specifically anti-Karaite work. I argue instead that Halevi's treatise is rather a reflection of an internal Jewish, cross-sectoral debate over the question of how to repair or heal (nota bene the author was a physician by profession) and improve the entire Jewish nation - Rabbanites and Karaites alike - and bring about their re-unification, thereby restoring Judaism to its former glory. This may, in turn, have a messianic (eschatological) purpose, namely, to usher in the ultimate redemption. Accordingly, the despised religion (Ar. al-din al-dalil) of the title may refer to the faith of all the Jews, including Karaites, who, according to Halevi, in some respects should be admired and emulated, while in others require rectification, just as do the representatives of mainstream Judaism.

As we have seen, in some respects Halevi was very close to the Karaite positions, for example, in his admiration of the Bible and the Hebrew language in which it was written, as well as his conviction about the paramount importance of the Land of Israel ("Palestinocentrism"), and the Temple in Jerusalem. ${ }^{68}$ In addition, the story of his life proves that his Zionism was not (only) a theoretical idea borne out in more or less conventional, poetical expressions of longings to the holy land; rather, just like the Karaite Mourners of Zion, he decided to put this ideal into practice by making the decision (highly surprising to his contemporaries) to leave his former life in al-Andalus behind and set out for Palestine, occupied at the time by the Crusaders. Furthermore, his notion of the binding nature of only that part of the corpus of the Oral Law that was revealed in the Land of Israel and, in consequence, his implicit undermining of the authority of the Jewish religious leadership in the diaspora, to some extent concurred with the Karaites' view of the "shepherds of the exile" (and, as a result, invited a polemical response on the part of Abraham ibn Daud). Moreover, Halevi's idea of the selected, chosen elite (Ar. șafwa) who are committed to

67 See Strauss, "The Law of Reason," 5 o.

68 On the paramount importance of the Land of Israel in the Karaite doctrine in general, and its extremist branch in particular, see Erder, The Karaite Mourners of Zion. For a number of other similarities between Halevi and the Karaites, see Lasker, Judah Halevi and Karaism, 115-118; idem, From Judah Hadassi, 145-147; Zawanowska, "Where is Anan." 
transmitting knowledge in secrecy, also resembles, at least to some extent, the Karaite conception of the righteous remnant which preserves - sometimes clandestinely - and teaches the true Torah (Heb. šěerït). Finally, from other sources than The Book of the Kuzari we learn that he held the Karaites in high esteem, calling them "God-fearing sons of Scripture" and "friends of God," and wishing them that they may strengthened, since, in his view, there was none like them among the nations. ${ }^{69}$

In support of his arguments, Halevi draws upon a wide array of sources and ideas - including Karaite ones - which he subjects to novel, often subversive, readings and unexpected interpretations (e.g., he asserts that the Rabbanite sages practice iğtihād, the hallmark of Karaism, and that the Rabbanite exilic way of life was tantamount to idolatry). All this demonstrates that the author negotiated the chief values of Judaism (e.g., revelation vs. reason; oral tradition vs. Scripture; Land of Israel vs. diaspora; individuals vs. community; Jewish people vs. Gentiles), partaking thereby in lively discussions that took place throughout the Middle Ages in all monotheistic traditions over their respective central ideas and formative concepts, which resulted in the crystallization of their distinctive traits as we know them today. It also proves Halevi's genuine originality and his ingenious as well as bold innovativeness, which occasionally required him to obfuscate the intended meaning of his message by means of understatements and purposefully ambiguous expressions, as if to diminish the intensity of his polemical outbursts. Accordingly, as I argue elsewhere, when the thrust of the author's criticism was directed against his Rabbanite brethren, not infrequently he veiled it under a deft cover of anti-Karaite polemics.

In all this, David plays a central role in Halevi's treatment of the aforementioned fundamental subjects discussed in the treatise. To mention just two additional examples, the exegetes' misunderstanding of David's words to Solomon, know the God of your father and serve Him, as referring to the necessity of acquiring knowledge of God prior to His worship, instead of reliance on tradition, is placed at the origin of the schism between the Rabbanites and Karaites, while another major factor that brought about the split, namely the calendar, is associated with (and passed through) David's House, via Hillel b. Judah.

To conclude, my analysis of Halevi's portrayal of the figure of David has served as a tool for investigating the broader question of the author's purpose in writing of The Book of the Kuzari and thereby also his attitude to the Jewry

696 "New Poems." Cf. Yahalom, Yehuda Halevi, 64. 
of his time, all the representatives of which, as I have tried to demonstrate, he critically examined with the aim of repairing and restoring their former unity.

\section{Bibliography}

\section{Primary Sources}

Abraham ibn Daud. Sēper ha-Qūbālā - see Cohen, Gerson D. (ed. and trans.). A Critical Edition with a Translation and Notes of the Book of Tradition (Sefer ha-Qabbalah) by Abraham ibn Daud.

Albeck, Chanoch, and Theodor, Julius (eds.). Midrash Bereschit Rabba. Berlin: Akademie Verlag, 1912-1929.

Cohen, Gerson D. (ed. and trans.). A Critical Edition with a Translation and Notes of the Book of Tradition (Sefer ha-Qabbalah) by Abraham ibn Daud. Philadelphia: The Jewish Publication Society of America, 1967.

Davidson, Israel (ed.). Book of the Wars of the Lord [Sefer Milhamot Ha-Šem]: Containing the Polemics of the Karaite Salmon ben Yeruham against Saadia Gaon [in Hebrew]. Philadelphia: The Jewish Publication Society Press, 1934.

Hawary, Muhammad (ed.). The Differences Between the Karaites and the Rabbanites in the Light of Genizah MSS [in Arabic]. Cairo: Dar El Zahraa, 1994.

Midrash Bereschit Rabba - see Albeck, Chanoch, and Theodor, Julius (eds.). Midrash Bereschit Rabbah.

Sa'adya Gaon. Kitāb al-radd 'ala 'Anan - see Seewald, Yudah. Kitab ar-radd 'ala 'Anan.

Salmon ben Yeruham. Book of the Wars of the Lord - see Davidson, Israel (ed.). Book of the Wars of the Lord.

Seewald, Yudah. Kitāb al-radd 'ala 'Anan (Sēper ha-hahȟašah 'al 'Anān) le-RaSaG (Sa'adya Gaon's Book of Refutation of 'Anan) [in Hebrew]. In Kōbeẹeṣ hișē giborìm, vol. 9, 1-8o. New York: Machon Plitat Sofrim, 2016 (Nisan 5776).

Yehudah Halevi. Kitāb al-radd wa-'-dalïl fì al-din al-dalïl (The Book of Refutation and Proof on Behalf of the Despised Religion). Ms. Cambridge, T.-S. Arabic N.S. 308.86.

Yehudah Halevi. Kitāb al-hujja wa-al-dalï fì nașrat al-dìn al-dalïl (The Book of Sign and Proof of the Victory of (or "in Support of") the Despised Religion). Ms. Oxford, Bodleiana, Poc. 284.

Yehudah Halevi. The Book of Refutation and Proof on the Despised Faith (The Book of the Khazars), edited by David Tzvi Baneth and Haggai Ben-Shammai [in Hebrew]. Jerusalem: Magnes Press, 1977.

Yehudah Halevi. The Book of the Kuzari, translated by Barry S. Kogan and Lawrence V. Berman, manuscript provided by the authors. 


\section{Secondary Literature}

Astren, Fred. Karaite Judaism and Historical Understanding, Columbia, SC: University of South Carolina Press, 2004.

Baneth, Dov Zvi (David Hartwig). "Some Remarks on the Autographs of Yehudah Hallevi and the Genesis of the Kuzari" [in Hebrew]. Tarbitz, 26 (1957), 297-303.

Ben-Shammai, Haggai. "On mudawwin - the Editor of the Books of the Bible in JudaeoArabic Exegesis." In Rishonim ve-Achronim: Studies in Jewish History presented to Avraham Grossman, edited by Joseph Hacker, Benjamin Z. Kedar, and Joseph Kaplan [in Hebrew]. Jerusalem: the Zalman Shazar Center for Jewish History, 2009, 73-110.

Ben-Shammai, Haggai. "Major Trends in Karaite Philosophy and Polemics in the Tenth and Eleventh Centuries." In Karaite Judaism: A Guide to its History and Literary Sources, edited by Meira Polliack [Handbook of Oriental Studies, vol. 73]. Leiden: Brill, 2003, 339-362.

Berger, Michael S. "Toward a New Understanding of Judah Halevi's Kuzari." The Journal of Religion, 72/2 (1992), 210-228.

Dinburg (Dinur), Ben-Zion. "The Immigration of Rabbi Judah Ha-Levi to the Land of Israel and the Messianic Fervor of his Day" [in Hebrew]. In Struggle of Generations, edited by Ben-Zion Dinburg (Dinur). Jerusalem: Mosad Bialik, 1975, 232-236.

Erder, Yoram. The Karaite Mourners of Zion and the Qumran Scrolls. Translated into English by Yaffah Murciano. Turnhout: Brepols, 2017.

Erder, Yoram. Methods in Early Karaite Halakha [in Hebrew]. Tel Aviv: Hakibbutz Hameuhad, 2012.

Erder, Yoram. "Second Temple Period Sectarian Polemic Concerning the Half-Shekel Commandment in Light of Early Karaite Halakhah" [in Hebrew]. Megillot: Studies in the Dead Sea Scrolls, 8-9 (2010), 3-28.

Fishman, Talya. Becoming the People of the Talmud: Oral Torah as Written Tradition in Medieval Jewish Cultures. Philadelphia: University of Pennsylvania Press, 2011.

Fleischer, Ezra, and Gil, Moshe. Yehuda Halevy and His Circle [in Hebrew]. Jerusalem: World Union of Jewish Studies, 2001.

Friedman, Mordechai A. "Judah Ha-Levi on Writing the Kuzari: Responding to a Heretic." In "From a Sacred Source": Genizah Studies in Honour of Professor Stefan C. Reif, edited by Ben Outhwaite and Siam Bhayro [Cambridge Genizah Studies Series, vol. 1], 157-169. Leiden: Brill, 2010.

Goitein, Shelomo Dov. Letters of Medieval Jewish Traders. Princeton, NJ: Princeton University Press, 1973-1974.

Goitein, Shelomo Dov. A Mediterranean Society: The Jewish Communities of the Arab World as Portrayed in the Documents of the Cairo Geniza, 6 vols. Berkeley - Los Angeles: University of California Press, 1967-1993; corrected edition 2000. 
Goitein, Shelomo Dov. "The Biography of Rabbi Judah ha-Lewi in the Light of the Cairo Geniza Documents." Proceedings of the American Academy for Jewish Research, 27-29 (1958-1961), 41-56.

Goitein, Shelomo Dov. “Autographs of Yehuda Halevi” [in Hebrew]. Tarbitz, 25/4 (1956), 393-412.

Goitein, Shelomo Dov, and Friedman, Mordechai A. India Traders of the Middle Ages: Documents from the Cairo Geniza ("India Book") [Études sur le judaïsme médiéval, vol. 34]. Leiden: Brill, 2008.

Goldstein, Miriam. Karaite Exegesis in MedievalJerusalem. The Judeo-Arabic Pentateuch Commentary of Yusuf ibn Nuh and Abu al-Faraj Harun. Tübingen: Mohr-Siebeck, 2011.

Gryczan, Barbara. "David as Warrior, Leader, and Poet in Medieval Hebrew Poetry of al-Andalus: Shmuel ha-Nagid's Self-portrait as 'the David of His Age." (In this volume).

Husik, Isaac. A History of Medieval Jewish Philosophy. Philadelphia: Jewish Publication Society of America, 1946.

Krinis, Ehud. God's Chosen People. Judah Halevi’s Kuzari and the Shĩ Imām Doctrine, translated into English by Ann Brener, Tamar Liza Cohen [Cultural Encounters in Late Antiquity and the Middle Ages, vol. 7]. Turnhout: Brepols, 2014.

Krinis, Ehud. "The Arabic Background of the Kuzari." Journal of Jewish Thought and Philosophy, 21/1 (2013), 1-56.

Krinis, Ehud. The Legitimist Inheritance Question and the Formation of the Idea of the Chosen People in Judah Halevi's Sefer HaKuzari. In Spiritual Authority: Struggles over Cultural Power in Jewish Thought, edited by Haim Kreisel, Boaz Huss, and Uri Ehrlich, 47-70 [in Hebrew]. Beer-Sheva: Ben Gurion University Press, 2009.

Lasker, Daniel L. From Judah Hadassi to Elijah Bashyatchi. Studies in Late Medieval Karaite Philosophy [Supplements to the Journal of Jewish Though and Philosophy, vol. 4]. Leiden - Boston: Brill, 2008, 143-144.

Lasker, Daniel L. Judah Halevi and Karaism. In From Ancient Israel to Modern Judaism: Intellect in Quest of Understanding: Essays in Honor of Marvin Fox, edited by Jacob Neusner, Ernest S. Frerichs, and Nahum M. Sarna. Atlanta, Georgia: Scholars Press, 1989, 111-125.

Levinger, Jacob. "The Kuzari and its Significance" [in Hebrew]. Tarbitz, 40 (1971), $742-782$.

Lobel, Diana. Between Mysticism and Philosophy: Sufi Language of Religious Experience in Judah Ha-Levi's Kuzari [sunY series in Jewish Philosophy]. Albany, NY: sUnY Press, 2000.

Neumark, David. Essays in Jewish Philosophy. Cincinnati: Central Conference of American Rabbis, 1929 . 
Polliack, Meira. "Karaite Conception of the Biblical Narrator (Mudawwin)." In Encyclopaedia of Midrash, edited by Jacob Neusner and Alan J. Avery-Peck, vol. 1, 350-374. Leiden: Brill, 2005.

Poznański, Samuel. "The Anti-Karaite Writings of Saadiah Gaon." Jewish Quarterly Review, o.s., 10 (1898), 238-276; repr. in Karaite Studies, edited by Philip Birnbaum, 89-127. New York: Hermon Press, 1971.

Ratzhabi, Jehudah. "New Poems of R. Yehudah Halevi" [in Hebrew]. Sinai, 113 (1993), 1-13.

Sasson, Ilana. "The mudawwin revisited: Yefet ben Eli on the composition of the Book of Proverbs." Journal of Jewish Studies, 67(2) (2016), 327-339.

Schirmann, Yefim (Hayim). A History of Hebrew Poetry and Drama: Studies and Essays [in Hebrew], 2 vols. Jerusalem: Mosad Bialik, 1980.

Schwartz, Dov. "The Messianic Idea in the Thought of Rabbi Judah Halevi and its Interpretation by Provencal Commentators on the Kuzari" [in Hebrew]. Sefunot, 21 (1993), 11-39.

Schweid, Eliezer. Reason and Analogy [in Hebrew], 37-79. Ramat Gan: Massadah Press, 1970.

Shear, Adam. The Kuzari and the Shaping of Jewish Identity, 1167-1900. Cambridge: Cambridge University Press, 2008.

Simon, Uriel. Four Approaches to the Book of Psalms: From Saadiah Gaon to Abraham ibn Ezra, translated into English by Lenn J. Schramm [sunY Series in Judaica]. Albany, NY: State University of New York Press, 1991.

Stern, Sacha. Calendar and Community: A History of the Jewish Calendar, 2nd century $B C E$-1oth century CE. Oxford: Oxford University Press, 2001.

Strauss, Leo. "The Law of Reason in the Kuzari." Proceedings of the American Academy for Jewish Research, 13 (1943), 47-96.

Wechsler, Michael G. The Arabic Translation and Commentary of Yefet ben 'Eli the Karaite on the Book of Esther [Karaite Texts and Studies, vol. 1, Études sur le judaïsme medieval, vol. 36]. Leiden: Brill, 2008.

Wolfson, Elliot R. "Merkavah Traditions in Philosophical Garb: Judah Halevi Reconsidered." Proceedings of the American Academy for Jewish Research, 57 (19901991), 179-242.

Yahalom, Joseph. Yehuda Halevi. Poetry and Pilgrimage. Jerusalem: The Hebrew University Magness Press, 2009.

Zawanowska, Marzena. "Reconstructing the Past and Conceptualizing the Jewish 'Other': How the Babylonian Geonim Contributed to the Creation of the Founding Myth of Karaism." History of Religions, forthcoming.

Zawanowska, Marzena. "The Art of Ambiguity: The Karaites as Portrayed in Judah Halevi's Book of the Kuzari." AJs Review, 1(45) (2021), 1-24. 
Zawanowska, Marzena. "Introduction. Yehudah ha-Levi and His Book of the Kuzari" [in Polish]. Kwartalnik Historii Żydów - Jewish History Quarterly, 2(266) (2018), 225-232. Zawanowska, Marzena. "Where is Anan? Yehudah ha-Levi and His Innovative Reconstruction of the Origins of Karaism. The Book of the Kuzari, chapter III, 64-67 - a Translation and Interpretation Attempt" [in Polish]. Kwartalnik Historii Żydów - Jewish History Quarterly, 2(266) (2018), 233-289.

Zawanowska, Marzena. "Was Moses the mudawwin of the Torah? The Question of Authorship of the Pentateuch According to Yefet ben 'Eli." In Studies in JudaeoArabic Culture: Proceedings of the Fourteenth Conference of the Society for JudaeoArabic Studies, edited by Haggai Ben-Shammai, Arad Dotan, Yoram Erder and Mordechai A. Freidman, $7^{*}-35^{*}$. Tel Aviv: Tel Aviv University Press, 2014.

Zawanowska, Marzena. "Ha'ataqa." In Encyclopedia of Jews in the Islamic World, edited by Norman A. Stillman, Phillip Isaac Ackerman-Lieberman et al., vol. 2, 189. Leiden Boston: Brill, 2010. 